\title{
New findings of airborne fungal spores in the atmosphere of Havana, Cuba, using aerobiological non-viable methodology
}

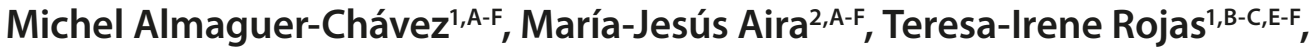 \\ María Fernández-González ${ }^{3, B-C, E-F}$, Francisco-Javier Rodríguez-Rajo ${ }^{3, B-C, E-F}$ \\ ${ }^{1}$ Department of Microbiology and Virology, Faculty of Biology, University of Habana, La Habana 10400, Cuba \\ ${ }^{2}$ Department of Botany, Faculty of Pharmacy, University of Santiago, Santiago de Compostela 15782, Spain \\ ${ }^{3}$ Department of Plant Biology and Soil Sciences, Faculty of Sciences, University of Vigo, 32004 Ourense, Spain \\ A - Research concept and design, B - Collection and/or assembly of data, C - Data analysis and interpretation, \\ $D$ - Writing the article, E-Critical revision of the article, F - Final approval of article
}

Almaguer-Chávez M, Aira MJ, Rojas TI, Fernández-González M, Rodríguez-Rajo FJ. New findings of airborne fungal spores in the atmosphere of Havana, Cuba, using aerobiological non-viable methodology. Ann Agric Environ Med. 2018; 25(2): 349-359. doi: 10.26444/aaem/89738

\section{Abstract}

Introduction. Although airborne fungal diversity in tropical countries is known to be considerable, aerobiological research to-date has identified only a part of the fungal mycobiota that may have an impact both on human health and on crops. Previous studies in Havana city identified only 30 genera and 5 spore types; therefore,new research is required in these latitudes. This study sought to investigate airborne spore levels in Havana, with a view to learning more about local fungal diversity and assessing its influence in quantitative terms.

Materials and method. A Hirst type volumetric sampler was located on the rooftop of a building 35 meters above ground level, in a busy area of the city. Sampling was carried out continuously (operating 24hours/day), at $10 \mathrm{~L}$ per minute during the year 2015. The fungal spores were collected on a Melinex tape coated with a $2 \%$ silicone solution. The results were expressed as spores per cubic meter (spores $/ \mathrm{m}^{3}$ ) of air when to referring to daily values, and spores count if referring to annual value.

Results. Fourteen new genera were identified in the course of volumetric sampling: six produce ascospores and eight conidia. Morphobiometric characteristics were noted for all genera, and airborne concentrations were calculated. These genera accounted for $56.4 \%$ of relative fungal frequency over the study year.

Conclusions. Many airbone fungi are primary causes of both respiratory disease and crop damage. These new findings constitute a major contribution to Cuba's aerobiological database.

\section{Key words}

airborne fungal spores, non-viable methodology, Havana, Cuba

\section{INTRODUCTION}

Aerobiological research seeks, among other things, to identify and quantify airborne fungal spores; its findings have a number of applications, for example, in preventing respiratory pathologies triggered by these bioparticles, in enhancing crop output and in conserving the cultural heritage [1-4]. Fungi have been identified as a major contributor to atmospheric bioaerosol levels in non-tropical countries, where they are known to increase the respiratory health risk for people reactive to fungal allergens. Spores may be released from a wide range of organic and non-organic substrates; small spore diameters favour propagation, environmental dispersion, and high airborne concentrations [5].

Sensitization to outdoor allergens has been reported in tropical environments such as Puerto Rico and Saudi Arabia [6,7], where basidiospores are the predominant fungal particles in the atmosphere. Some epidemiological studies evidence a high rhinitis-asthma prevalence (55.3\%) among school children [8]. However, although numerous studies have described the tropical flora, information about

Address for correspondence: María-Jesús Aira, Universidade de Santiago, 15701 Santiago de Compostela, Spain

e-mail: mariajesus.aira@usc.es

Received: 25.04.2017; accepted: 04.04.2018; first published: 09.05.2018 the allergenic properties of pollens and moulds is scarce. Furthermore, its contribution to allergic respiratory diseases has not been extensively studied as has occurred with mitosporic fungi $[9,10]$.

Viable and non-viable sampling methods have been used to investigate airborne spore diversity in a number of areas [11, 12]. The present study used a non-viable sampling method based on Hirst-type spore traps. The chief advantages of this approach, which provides information on total airborne spore concentrations regardless of their viability, are that it is easy to implement and that it enables seasonal, daily and hourly data to be rapidly obtained.

In contrast, viable-spore volumetric collection methods are much more laborious, since identification requires the preparation of appropriate culture media for sporulation, followed by the isolation, incubation and development of different colonies. In addition, the spore visual identification allows us to establish annual calendars of moulds transported by the air, as well as to know their dynamics at different time scales. This fact was extremely important for improving the quality of life of people suffering from these pathologies. Moreover, this information also helps us to avoid damages to urban crops as higher concentration of airborne spores are related to the peak of the fungal infection. This knowledge allow us to enhance the decisions of the phytosanitary 
treatments application [13-15], with the optimization of the crops harvest, such as rice, so important for the Cubans diet [16].

Finally, objects forming part of the cultural heritage may provide an excellent substrate for fungal colonization, leading to the biodeterioration of various kinds of material and the release of airborne biological particles which may be hazardous to visitors and users of enclosed spaces [17]. Research has shown that this is particularly significant in indoor environments such as museums $[18,19]$.

A number of studies have highlighted the considerable fungal diversity and high airborne concentrations found in tropical countries [20,21]. Earlier research in Havana, Cuba, identified around 30 genera; the number varied slightly depending on whether viable or non-viable sampling methods were used [11, 22]. Cladosporium, Aspergillus and Penicillium were the predominant genera. Relative humidity is regarded as the weather-related variable most influencing airborne spore concentrations. To-date, there has been little research undertaken using volumetric methods, even though these would help to provide data for a large number of sampling years, thus contributing to a fuller characterization of Cuba's airborne fungal biota. An extensive database is essential for the construction of models to predict airborne spore concentrations. Moreover, the local airborne mycobiota in any given area is influenced by a range of factors which might directly affect the source of the inoculum, either through human activity or through the effects of climate change [23].

\section{OBJECTIVE}

The aim of this study was to provide new findings about the fungal spores content of the bioaerosol in Havana, in order to increase knowledge of the fungal diversity in this area, and to ascertain its incidence from a quantitative point of view. The presented study therefore examined the impact of weatherrelated variables on spore diversity and concentrations both over the study year and over previous periods.

\section{MATERIALS AND METHOD}

Study area. The study was carried out in Havana (Fig. 1) located on the northern coast of the island of Cuba, at an altitude of $24 \mathrm{~m}$ above sea level. It is the largest city in Cuba and has a population of more than 2 million inhabitants (approx. 20\% of the population in Cuba). Near the location of the volumetric sampler there is no dense vegetation, although

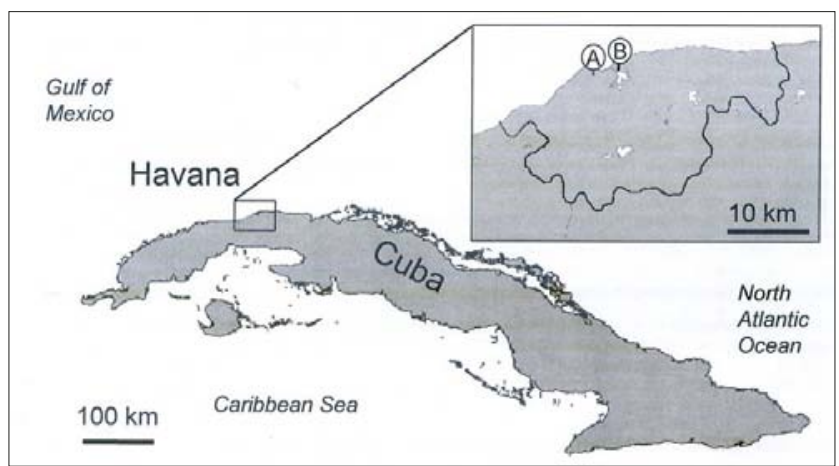

Figure 1. Location of Havana city (A, spore sampler; B, meteorological station) there are numerous gardens with a wide variety of trees, shrubs, and ornamental plants that are part of the city's layout $[24,25]$. The climate of Cuba is subtropical, characterized by the alternation of two weather seasons throughout the year based on accumulative rainfall: a dry (November - April) and a rainy season (May - October). Havana's climate exhibits mid-continental characteristics: somewhat cold winters and warm, humid summers. In addition, most of the precipitation occurs during the warmer months, and there are rather large variations in yearly temperature and precipitation.

Sampling and microscopic examination methodology. Light microscopy was used to analyze samples collected using a Lanzoni VPPS 2000 Hirst-type volumetric sampler (Lanzoni s.r.l., Bologna, Italy) [26], located on the roof of the Biology Faculty building of the University of Havana, $35 \mathrm{~m}$ above ground level ( $23^{\circ} 08^{\prime} \mathrm{N}$; 82 $\left.2^{\circ} 23^{\prime} \mathrm{W}\right)$. Sampling was carried out continuously (operating 24 hours/day), at $10 \mathrm{~L}$ per minute, from 1 January - 31 December 2015.

Inside the sampler, the fungal spores were collected on a Melinex tape coated with a $2 \%$ silicone solution. The fungal spore quantification was carried out following the methodology of the Spanish Aerobiology Network [27]. The results were expressed as spores per cubic meter of air $\left(\right.$ spores $/ \mathrm{m}^{3}$ ) when referring to daily values, and spores considered as the total spore value. This methodological proposal is subject to quality controls for its data contributors $[28,29]$. The spore types collected were described by means of the morphotypes, as defined by Saccardo [30], as well as its morphobiometrical characteristics. The spore identification was conducted only at genera level. For this purpose, classic reference handbooks in taxonomy and aerobiology [31-37] as well as specialized papers [38-42] were consulted. Morphological identification was performed by means an optical Nikon Optiphot II microscope (Nikon Manufacturing, Tokyo, Japan). The magnification used was $400 \mathrm{X}$ for counting and in some cases $1000 \mathrm{X}$ to achieve better fungal spore recognition. The spore photographs, included in this study, were obtained with a Nikon camera (Coolpix MDC lens) assembled to the microscope, using a dry $60 \mathrm{x}$ lens.

Statistical analysis. Spore abundance and frequency were taken as relative values, derived from percentages, with a view to obtaining a ranked classification of species using the Olmstead-Tukey test (Tab. 1). Relative density (RD) was calculated using spore count data (each new record and totals) by means of the following equation: $\mathrm{RD}=$ (amount of a given spore/amount of total spores identified $)^{\star} 100$. Relative Frequency was calculated as follows: $\mathrm{RF}=$ (number of days on which a determined spore was detected / total sampling days)* 100 .

To determine the influence of weather-related variables on airborne spore counts, Spearman's test was used since data distribution was non-normal. The Statistica v. 6.0 software package for Windows [43] was used for this purpose. Correlations were examined over the study year

Table 1. Criteria used for relative frequency and density

\begin{tabular}{cc} 
Category & Criterion \\
\hline Dominant & RF and RD values higher than the mean values \\
Constant & RD value below mean, but the RF is above mean \\
Occasional & RD value above mean, but with lower RF \\
Rare & RF and RD are lower than their means
\end{tabular}


(2015) and previous periods (2011-2014) in order to obtain further information regarding the influence of weatherrelated variables on spore production. The daily values of the meteorological variables were recorded by the meteorological station at Casablanca (placed $4 \mathrm{~km}$ from the sampler) and supplied by the Cuban Institute of Meteorology (INSMET, http://www.met.inf.cu). The significance was calculated for the $\mathrm{p}$ value $\leq 0.05$.

\section{RESULTS}

Qualitative analysis. In the course of 2015, a total of 27 fungal spore types were identified using the standard methodology recommended by the Spanish Aerobiology
Network; 14 of these had not previously been recorded locally (Tab 2; Fig. 2). Six were Ascomycetes (Chaetosphaerella, Diaporthe, Didymosphaeria, Leptosphaerulina, Massarina and Mauritiana) and eight conidial genera (Acrodictys, Arthrinium, Ceratosporium, Corynespora Helminthosporium, Lasiodiplodia, Polythrincium and Zygophiala). Among the ascospores, three fragmospores, two didymospores and one dictyospore were identified. Didymospore conidia predominated among the eight genera evaluated.

Quantitative analysis. The total spore count was 200,451 (Tab.3). Cladosporium was the most abundant (117,770 spores), followed by Leptosphaeria (26,336 spores), Coprinus $(18,398)$ and Aspergillus/Penicillium (12,746). Attention is drawn to the contribution of Xylariaceae ascospores and Curvularia

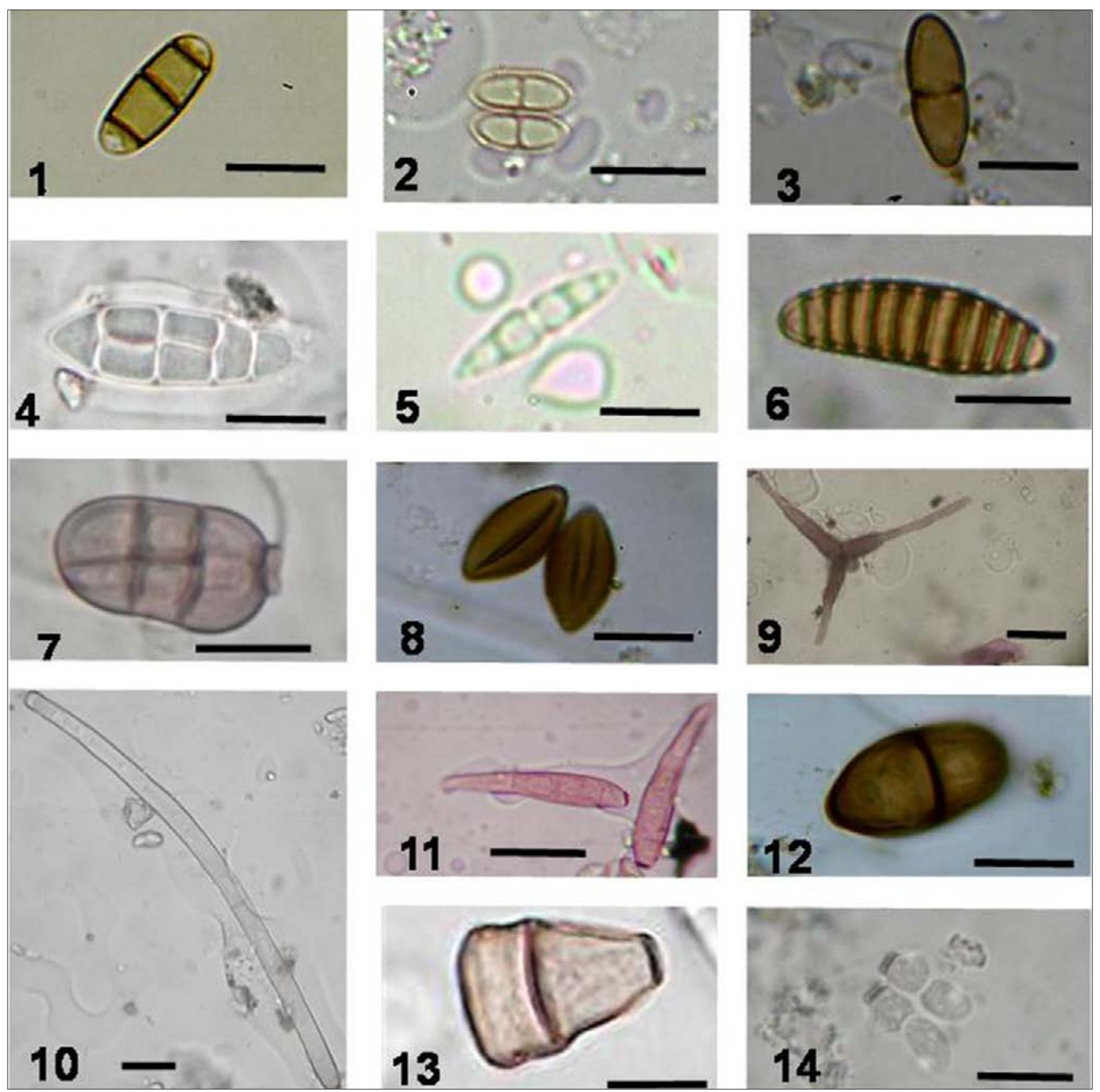

Figure 2. Photomicrographs of airborne spores recorded by non-viable method in the atmosphere of Havana, Cuba during 2015. 1-6: Ascospores. 7-14: Conidia. 1. Chaetosphaerella, 2.Diaporthe, 3. Didymosphaeria, 4.Leptosphaerulina, 5.Massarina, 6.Mauritiana, 7.Acrodictys, 8.Arthrinium, 9.Ceratosporium, 10.Corynespora, 11. Helminthosporium, 12.Lasiodiplodia, 13.Polythrincium. 14. Zygophiala. Scale bars: $10 \mu \mathrm{m}$. 


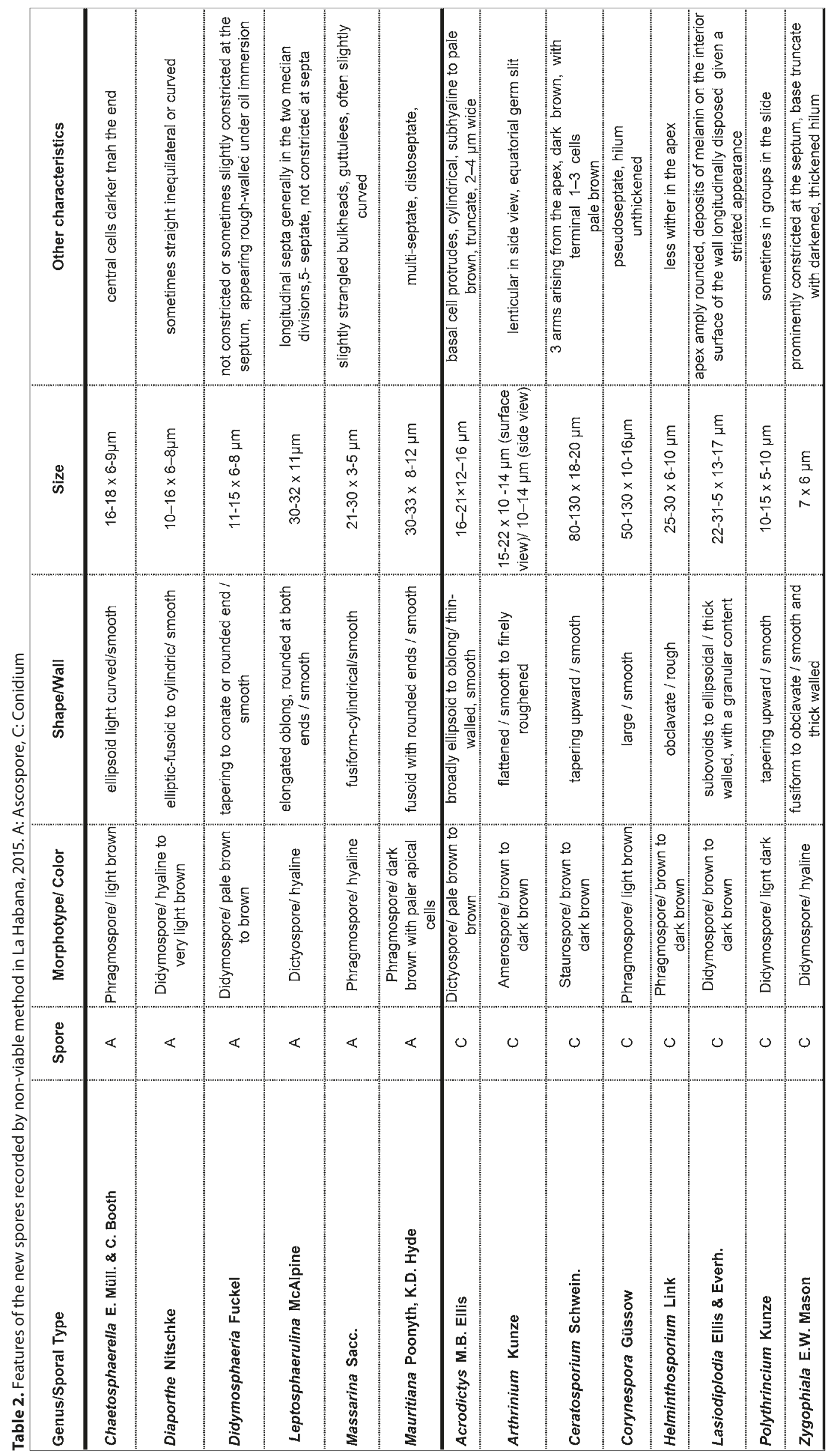


Table 3. Aerobiological data of fungi identified in the atmosphere of Havana during 2015

\begin{tabular}{|c|c|c|c|c|}
\hline Fungi & Total spores & Days & Maximun (spores $/ \mathrm{m}^{3}$ ) & Date of maximum \\
\hline Cladosporium & 117770 & 365 & 3942 & 3-Jun \\
\hline Leptosphaeria & 26336 & 351 & 733 & 8-Nov \\
\hline Coprinus & 18398 & 350 & 677 & 15-Jun \\
\hline Aspergillus/Penicillium & 12746 & 348 & 276 & 18-Sep \\
\hline Xylariaceae & 3961 & 246 & 197 & 16-Nov \\
\hline Curvularia & 2949 & 334 & 92 & 15-Jul \\
\hline Nigrospora & 2719 & 322 & 50 & 15-May \\
\hline Periconia & 2549 & 257 & 122 & 10-May \\
\hline Venturia & 1618 & 160 & 109 & 28-Mar \\
\hline Cercospora & 1400 & 198 & 53 & 31-Dec \\
\hline Ganoderma & 1422 & 247 & 37 & 14-Jul \\
\hline Monodictys & 1142 & 138 & 58 & 1-Nov \\
\hline Uredospores & 909 & 151 & 58 & 20-Jan \\
\hline Diaporthe & 198 & 46 & 19 & 23-Nov \\
\hline Didymosphaeria & 192 & 49 & 24 & 15-Nov \\
\hline Massarina & 173 & 64 & 17 & 4-May \\
\hline Helminthosporium & 147 & 49 & 37 & 22-Jan \\
\hline Lasiodiplodia & 76 & 50 & 4 & 15-Nov 9-Dec \\
\hline Corynespora & 68 & 41 & 5 & 1-Nov \\
\hline Polythrincium & 48 & 19 & 6 & 4-Dec \\
\hline Arthrinium & 41 & 12 & 17 & 1-Nov \\
\hline Leptosphaerulina & 33 & 18 & 6 & 24-Jan \\
\hline Chaetosphaerella & 27 & 20 & 3 & 6-May \\
\hline Mauritiana & 17 & 14 & 2 & 21-Apr 17-Nov \\
\hline Acrodictys & 6 & 5 & 2 & 19-Nov \\
\hline Zygophiala & 4 & 2 & 2 & 22-Jan 1-Nov \\
\hline Ceratosporium & 3 & 3 & 1 & - \\
\hline Other conidia & 4985 & 344 & 90 & 20-Jan \\
\hline Other Ascospores & 513 & 170 & 17 & 20-Jan \\
\hline Total identified spores & 200451 & 365 & & \\
\hline Total new findings & 1033 & 206 & $\mathrm{RF}=56,4 \%$ & $\mathrm{RD}=0,52 \%$ \\
\hline
\end{tabular}

Note: Genera in bold are the new findings presented in this study

conidia, although these genera were regarded as secondary in quantitative terms, in view of total annual values. Additional spores detected included other ascospores (Chaetomium, Paraphaeosphaeria, Pleospora and Sporormiella) and conidial fungi (Alternaria, Beltrania, Bipolaris, Epicoccum, Fusarium, Gliomastix, Helicoma, Helicomyces, Pestalotia, Pithomyces, Pseudocercospora, Pyricularia, Spegazzinia, Sporidesmium, Stemphylium, Tetraploa and Torula), with a contribution of 513 and 4985 spores, respectively.

Newly-detected airborne fungi with fairly high spore counts (147-198) included Diaporthe, Didymosphaeria, Massarina and Helminthosporium. Most recorded high daily concentrations during the dry season (November-April); Helminthosporium displayed the highest counts $\left(37 \mathrm{spores} / \mathrm{m}^{3}\right.$ on 22 January), followed by Didymosphaeria (24 spores $/ \mathrm{m}^{3}$ on 15 November). By contrast, Chaetosphaerella and Massarina reached peak counts in May, i.e. during the rainy season. Seven of the traditionally identified genera in the Havana atmosphere had maximum peaks during the rainy months (Cladosporium, Coprinus, Aspergillus/Penicillium, Curvularia, Nigrospora, Periconia and Ganoderma) and six reached maximum concentrations during the dry season (Leptosphaeria, Xylariaceae, Venturia, Cercospora, Monodictys and Uredospores).

A total of 1,033 spores belonged to newly-identified genera, with a relative density of $0.52 \%$ and a relative frequency of $56.4 \%$ were recorded (Tab. 4). Ranked classification of the airborne fungi identified suggested that spores belonging to these genera detected were rare. Relative frequency and relative density values were lower than the mean for each of these ecological estimators: $\mathrm{RF}=0.5-17.5 \%$ and $\log (\mathrm{RD}+1)=0.001-$ 0.036 . They share the same ranked classification as Epicoccum, Pseudocercospora, Sporidesmium, Pleospora, Helicomyces, Helicoma, Chaetomium, Paraphaeosphaeria, Stemphylium, Pestalotiopsis, Beltrania, Tetraploa, Spegazzinia, Pyricularia, Sporormiella and Gliomastix. Spores belonging to the Frequent category (Alternaria, Bipolaris, Fusarium, Monodictys, Torula, Pithomyces and Uredospores) or to the 
Table 4. Potential, ecology and reports of new genera recorded in Havana

\begin{tabular}{|c|c|c|c|}
\hline & Potentiality & Ecology & Report/Methodology/Author \\
\hline \multicolumn{4}{|c|}{ Ascospores } \\
\hline Chaetosphaerella & & PS, FG & ${ }^{*} \mathrm{Vnv}$ \\
\hline Diaporthe & $\mathrm{Ph}$ & PP, PS & ${ }^{*}$ Vnv \\
\hline Didymosphaeria & $\mathrm{Ph}$ & $\mathrm{T}, \mathrm{C}, \mathrm{SS}, \mathrm{PS}$ & ${ }^{*} \mathrm{Vnv}$ \\
\hline Leptosphaerulina & & $\mathrm{T}, \mathrm{PS}, \mathrm{PP}$ & ${ }^{*} \mathrm{Vnv}$ \\
\hline Massarina & & $T, W S, P S$ & ${ }^{*} \mathrm{Vnv}$ \\
\hline Mauritiana & & $\mathrm{T}$ & ${ }^{*} \mathrm{Vnv}$ \\
\hline \multicolumn{4}{|c|}{ Conidia } \\
\hline Acrodictys & & PS & ${ }^{*} \mathrm{Vnv}$ \\
\hline Arthrinium & $\mathrm{A}, \mathrm{Ph}, \mathrm{Hp}$ & C, PS & ${ }^{*} \mathrm{Vnv}$ \\
\hline Ceratosporium & & PP & ${ }^{*} \mathrm{Vnv}$ \\
\hline Corynespora & $\mathrm{A}, \mathrm{Ph}$ & $\mathrm{F}$ & Herrera et al., 2003-GnV \\
\hline Helminthosporium & $\mathrm{A}, \mathrm{Ph}$ & C & Herrera et al., 2003-GnV \\
\hline Lasiodiplodia & $\mathrm{Ph}$ & $\mathrm{C}$ & Arnold et al., 1987-GV; Almaguer et al. 2016-GV \\
\hline Polythrincium & $\mathrm{Ph}$ & PP & ${ }^{*} \mathrm{Vnv}$ \\
\hline Zygophiala & $\mathrm{Ph}$ & $\mathrm{T}, \mathrm{PP}$ & ${ }^{*}$ Vnv \\
\hline
\end{tabular}

Potentiality: A-Allergenic, Hp-Human or animal pathogen, Ph-Phytopatogen. Ecology: C-Cosmopolitan, F. Foliicolous, FG- Fungicolous, PP- Plant parasite, PS-Plant saprophyte, SS- soils saprophyte, T- Terrestial, WS Wood saprophyte. Report: *First citation in this study. Methodology: Vnv- Volumetric non viable, GnV- Gravimetric non-viable, GV- Gravimetric viable.

Table 5. Correlations between the main meteorological parameters and concentrations of traditionally recorded spores during $2011-2015$ ( $n=1826$ ) and new-recorded spores during $2015(n=365) .{ }^{*}$ Spearman's rank correlation coefficient significant are marked in bold $(r s)$ at $p<0,05$

\begin{tabular}{|c|c|c|c|c|c|c|c|}
\hline \multirow{2}{*}{$\begin{array}{c}\text { Traditionally recorded } \\
\text { spores }\end{array}$} & \multicolumn{3}{|c|}{$(2011-2015) n=1826$} & \multirow{2}{*}{$\begin{array}{l}\text { New recorded } \\
\text { spores }\end{array}$} & \multirow[b]{2}{*}{ Tmean } & \multirow{2}{*}{$\begin{array}{c}n=365 \\
\text { Rhmean }\end{array}$} & \multirow[b]{2}{*}{ Rainfall } \\
\hline & Tmean & Rhmean & Rainfall & & & & \\
\hline Leptosphaeria & $0,182^{\star}$ & $0,458^{*}$ & $0,242^{*}$ & Chaetosphaerella & 0,021 & $0,136^{*}$ & $0,207^{*}$ \\
\hline Xylariaceae & $0,100^{\star}$ & $0,264^{*}$ & $0,083^{*}$ & Diaporthe & $-0,121^{*}$ & $0,243^{*}$ & $0,241^{*}$ \\
\hline Venturia & $0,094^{*}$ & $0,198^{*}$ & $0,152^{\star}$ & Didymosphaeria & $-0,024$ & $0,155^{\star}$ & $0,184^{*}$ \\
\hline Coprinus & $0,360^{\star}$ & $0,392^{\star}$ & $0,147^{*}$ & Leptosphaerulina & $-0,125^{*}$ & 0,031 & $-0,006$ \\
\hline Ganoderma & $0,347^{*}$ & $0,248^{*}$ & $0,079^{*}$ & Massarina & $-0,089$ & $0,227^{\star}$ & $0,250^{*}$ \\
\hline Uredospores & $-0,229^{*}$ & $-0,070^{*}$ & $-0,117^{\star}$ & Mauritiana & 0,075 & 0,099 & $0,127^{*}$ \\
\hline Cladosporium & $-0,006$ & $0,104^{*}$ & 0,020 & Acrodictys & $0,118^{*}$ & $-0,051$ & $-0,083$ \\
\hline Aspergillus/Penicillium & 0,050 & $0,139^{*}$ & 0,050 & Arthrinium & $0,117^{*}$ & $-0,036$ & $-0,023$ \\
\hline Curvularia & $0,156^{\star}$ & $0,151^{*}$ & $-0,036$ & Ceratosporium & 0,012 & $-0,001$ & $-0,064$ \\
\hline Nigrospora & $0,135^{\star}$ & $0,104^{*}$ & $-0,068^{*}$ & Corynespora & $0,115^{\star}$ & $0,191^{*}$ & 0,002 \\
\hline Periconia & 0,057 & $0,156^{*}$ & $-0,028$ & Helminthosporium & $-0,087$ & 0,045 & $-0,035$ \\
\hline Cercospora & $0,175^{\star}$ & $0,193^{*}$ & 0,040 & Lasiodiplodia & $-0,018$ & $-0,002$ & 0,075 \\
\hline \multirow[t]{2}{*}{ Monodictys } & $-0,105^{\star}$ & $0,161^{*}$ & $-0,049$ & Polythrincium & 0,096 & $0,165^{*}$ & $0,127^{*}$ \\
\hline & & & & Zygophiala & $-0,007$ & 0,066 & 0,042 \\
\hline
\end{tabular}

Dominant one (Cladosporium, Leptosphaeria, Coprinus Aspergillus/Penicillium, Curvularia, Nigrospora, Ganoderma, Periconia, Xylariaceae, Cercospora and Venturia) can be also differentiated.

Correlations between spore counts and weather-related variables were weak throughout 2015, for both traditionallyrecorded and newly-detected spores (Tab. 5). Among the spores detected from 2011-2015, Spearman significant values ranged between $r_{s}=-0.068$ and $r_{s}=0.458(p<0.05 ; n=1,826)$. The results show that the airborne concentration of Leptosphaeria, Coprinus, Xylariaceae, Venturia and Ganoderma is positively correlated with all the meteorological factors, whereas negatively correlated for Uredospores. Relative humidity was the only weather-related variable displaying any correlation with all the spores in this group; in most cases, a positive correlation was observed. Significance values in the Spearman test for the 14 newly-recorded spores during 2015 ranged between $r_{s}=0.117$ (Arthrinium with Tmin) and $r_{s}=0.250$ (Massarina with rainfall). The influence of the variables tested was positive, with the exception of mean temperature in Diaporthe and Lepthosphaerulina.

\section{DISCUSSION}

The spores of fourteen new fungal genera recorded in the air of Havana were described. Many of these fungi display allergenic potential, and may pose a risk for human health as well as causing damage to crops [44]. Chaetosphaerella is characterized by three septum, smooth, fusiform, with 
brown median cells and hyaline end cells. Massarina are fusiform to cylindrical ascospores, hyaline, 1- to 3-septate, with or without a mucilaginous sheath. Mauritiana spores are fusoid with rounded ends, dark brown with paler apical cells, multi-septate, distoseptate and slightly constricted in the primary septum. Finally, two didymospores were found: Didymosphaeria has an ellipsoid shape, brown and 1-distoseptate, whereas the Diaporthe genus is bicellular, elliptic-fusoid to cylindric, slightly constricted at the septum, and sometimes irregularly shaped and containing oil drops. Leptosphaerulina is related to dictyospores, which may be hyaline or pigmented, and broadly clavate; the upper hemisphere usually displays one transverse septum and a somewhat narrowly-rounded end; the lower hemisphere usually has two transverse septa and broadly-rounded ends, a slightly constricted primary septum, and in most cases, one vertical septum in each smooth central cell.

Spores identified as Lasiodiplodia were brown to dark brown, subovoid to ellipsoidal, thick-walled, with granular content, a widely-rounded apex, and melanin deposits on the interior surface of the wall, longitudinally arranged to give a striated appearance. Polythrincium had large obovate uniseptate spores that appeared to taper slightly in an upward direction. Zygophiala displayed a single conidium, fusiform to ellipsoidal or obclavate, hyaline, smooth and thick-walled, with a single tranverse septum, $12-19 \times 4-6 \mu \mathrm{m}$, strongly constricted at septum, apex subobtuse, base subtruncate, with a dark, thickened hilum, 1-2 $\mu$ m wide.

Helminthosporium and Corynespora spores were thicker and longer. Ceratosporium estaurospores, amerospores of Arthrinium and dictyospores of Acrodictys were found with a lesser frequently. The Ceratosporium conidia are smooth and characterized by arms that arise from a two-celled basal body of the conidium. These arms are variable in length and septa, or sometimes very narrow. Spores identified as Arthrinium were aseptate, brown to dark brown, smooth to verruculose, of various sizes and shapes (globose, ellipsoidal, lenticular, angular, kidney-shaped, lobed or dentate in surface view), mainly flattened, with equatorial slit of lighter pigment. Acrodictys was characterized by broadly ellipsoid to oblong muriform conidia, usually with three transverse and several longitudinal septa, slightly constricted at the septa, pale brown, thin-walled, smooth; protruding basal cell, cylindrical, subhyaline to pale brown, truncate.

Cladosporium was the predominant genus, followed by Leptosphaeria, Coprinus and Aspergillus/Penicillium. Most of these fungi are saprophytes of dead organic material or plant pathogens parasites. For this reason, most outdoor airborne fungal spores originate from farms, forest stands and decomposing plant matter [45]. The marked incidence of these fungi and their impact on human health has been studied in different parts of the world [46-49]. Moulds are common aeroallergens, and Cladosporium is considered to be among the most prevalent [50]. In Santiago de Chile, for example, Cladosporium concentration attained $70.9 \%$ of the total spore count [51].

Previous studies have reported the detection of Phoma and Pithomyces, anamorphs of Didymosphaeria and Leptosphaerulina, respectively [11].

Corynespora and Helminthosporium genera were observed in the air of Santa Clara in the central area of Cuba, by the exposure of impregnated slides in glycerin plus phenol at $2 \%$ [52], although this study only provides qualitative information. Recently, airborne Lasiodiplodia spores were also detected in Havana using viable sampling techniques [53]. As shown in the database compiled by Camino et al. [54], in Cuba there have been detected several species of the genera Diaporthe (4 sp.), Didymosphaeria (3 sp.), Leptosphaerulina (2 sp.), Massarina (1sp.), Acrodictys (14 sp.), Arthrinium (6 sp.), Ceratosporium (2 sp.), Corynespora (12 sp.), Helminthosporium (12 sp) and Lasiodiplodia (1 sp.) in different environments. However, its spores had never hitherto been detected in the air, nor was it clear until now that it could occur in the general urban mycobiota.

Arthrinium, Helminthosporium and Corynespora commonly appear as saprobes on grasses, leaves, stems and roots in a range of different plant substrates [30-40]. Didymosphaeria is a widely-distributed genus with terrestrial, saprobic or parasitic habitat [41]. Massarina present a terrestrial, saprobic habitat, as well as the Leptosphaerulina genera, which additionally could be observed on monocotyledons or dicotyledons plants. Zygophiala was previously reported in the Caribbean region as the cause of banana leaf speckle in Jamaica [55] and of flyspeck on apples from China [56]. Polythrincium has been identified in European aerobiological research carried out in Leiden, Netherlands [47] and Szczecin, Poland [50]. Chaetosphaerella has been reported by Grant [19] in the air of the United States, along with a spore characterized as Boerlagella, which shares many similarities with the spore detected here, but is not currently an accepted taxon. Mauritiana is now accepted, and was first described as a new genus by Poonyth et al. [57], and is regarded as a terrestrial saprobic fungus able to grow in the tropics [41].

Although the airborne concentrations of recentlydocumented fungi (1,033 spores) were not high, it is important to confirm their presence in Havana. Some of these new genera are recognized allergens, such as Arthrinium, Corynespora, Helminthosporium and Polythrincium [58]. Although neither Leptosphaerulina nor Corynespora are officially reported as main allergens, studies conducted by Green et al. [59] demonstrated the presence of allergens in Leptosphaerulina. In addition, these ascospores have been reported with variable frequency in the atmosphere of different geographical areas, e.g. in Melbourne, Australia $(0.03 \%$ of the total spore content) [60], Madrid, Spain (0.02$0.8 \%$ ) [61], Crete and Greece, [62]. By contrast, sensitization to Corynespora has been reported among atopic and nonallergic subjects [63]. Although Corynespora is a common and widely- distributed pathogen, its spores are less often reported than those of other genera in aerobiological studies. The presence of their spores have been mainly detected in tropical countries, such as in West Bengal (0.45\%) [64], Kolkata, India (0.25\%) [65] and Karachi, Pakistan $(<1 \%)$ [48].

Massarina is not an allergenic fungus, and few reports document airborne spores in other tropical countries. The fungus has been reported at low densities in the outdoor air of Karachi, Pakistan [48]. By contrast, hypersensitivity to Helminthosporium antigens has been demonstrated by Simon-Nobbe et al. [66]. Airborne spores have been reported in Spain, where they accounted for less than $0.01 \%$ of total spores [67].

Recently, Martínez et al. [68] detected an airborne fungal group comprising mainly hyaline to pigmented distoseptate phragmoconidia in Montevideo City, Uruguay. This group included the four above-mentioned genera in addition to 


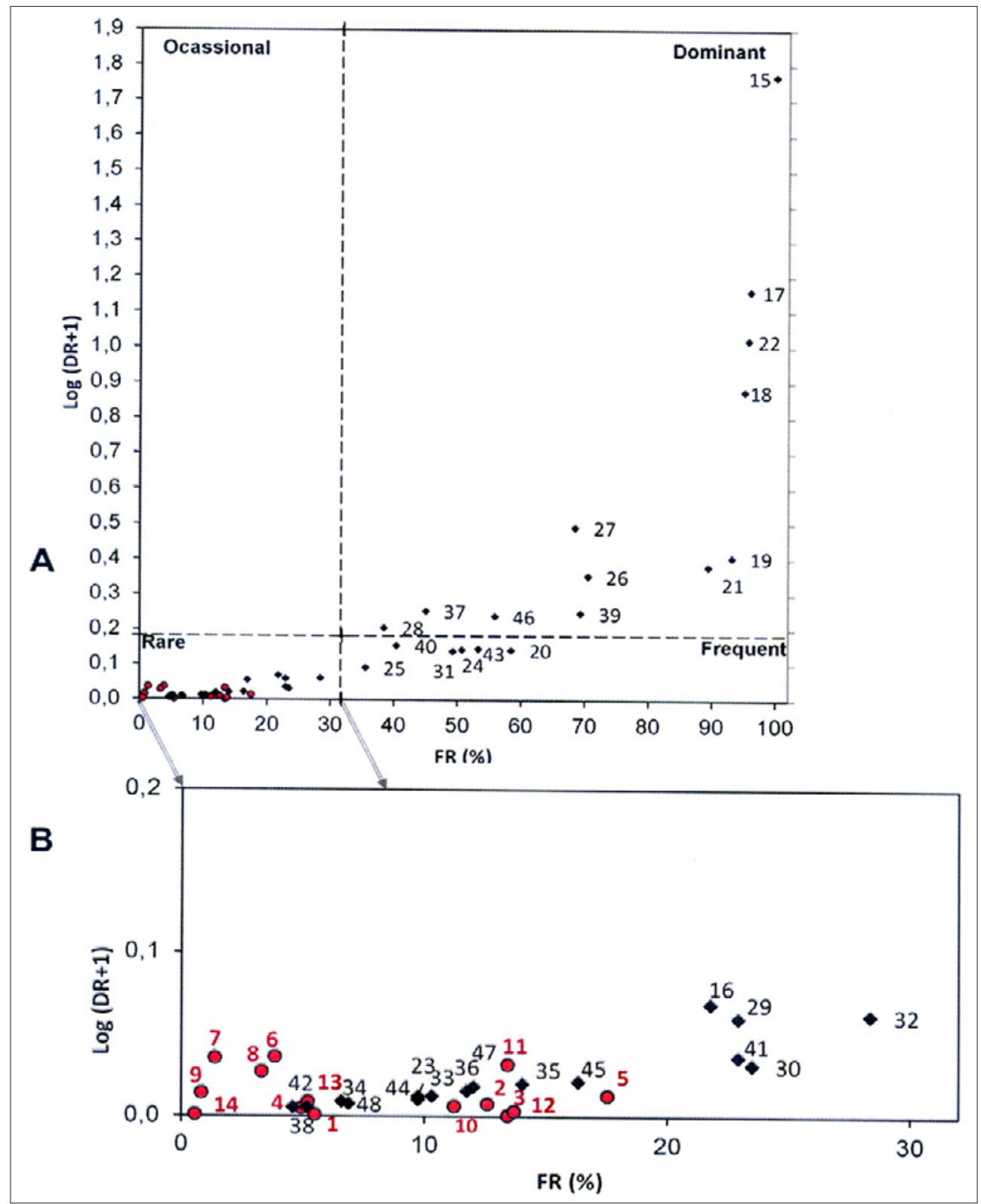

Figure 3. A: Olmstead-Tukey diagram showed the relationship between frequency and abundance of the airborne fungi identified in Havana during 2015. The dashed lines correspond to the mean abundance (horizontal) and occurrence (vertical) and are used to define the occasional, dominant, rare and frequent. Numbers from 1 to $14 \mathrm{In}$ red New spores recorded: 1.Chaetosphaerella, 2.Diaporthe, 3.Didymosphaeria, 4.Leptosphaerulina, 5.Massarina, 6.Mauritiana, 7.Acrodictys, 8.Arthrinium, 9.Ceratosporium, 10.Corynespora, 11. Helminthosporium, 12.Lasiodiplodia, 13.Polythrincium. 14.Zygophiala. In black 15 to 49: previously reported spores: 15:Cladosporim, 16:Gliomastix, 17:Lepthosphaeria, 18:Aspergillus/Penicillium, 19:Curvularia, 20:Alternaria, 21:Nigrospora, 22:Coprinus, 23:Epicoccum, 24:Fusarium, 25:Torula, 26:Periconia, 27:Xylariaceae, 28:Monodictys, 29:Pseudocercospora, 30:Sporidesmium, 31:Pithomyces, 32:Pleospora, 33:Helicomyces, 34:Helicoma, 35:Chaetomium, 36:Paraphaeosphaeria, 37:Venturia, 38:Stemphylium, 39:Ganoderma, 40:Uredosporas, 41:Pestalotiopsis, 42:Beltrania, 43:Bipolaris, 44:Tetraploa, 45:Spegazzinia, 46: Cercospora, 47:Pyricularia, 48: Sporormiella. The area between the origin (0;0) and the intercept of means $(31,75 ; 0,18)$ corresponding to RARE genera or spore types, area. B:Zoom of the portion corresponding to rare fungi.

Exosporium and Sporidesmium. However, previous studies in Havana reported the presence of Bipolaris and Sporidesmium, but with distinguishable spore features than those described in previous studies [69]. In other tropical areas, as well as India and North-central Nigeria, they are commonly reported, but under low frequency and density levels [64, $70,49]$. These spores have also been reported in Chile [51], Spain [71, 67], Italy [72] and Greece [73], where they account for less than $1 \%$ of total airborne spores.

Some of these recently-documented fungi (Diaporthe, Corynespora, Helminthosporium and Lasiodiplodia) were also identified as important phytopathogens in Cuba [74]. These fungi can damage a number of crops playing a major role in urban agriculture in outlying areas of the city, such as Citrus spp, and Manguifera indica [75]. Many Helminthosporium species are common parasites of the Poaceae family. Urban agriculture differs from the conventional because it presents fewer cultivated areas, is located on the periphery of cities, and has a greater diversity of crops or people involved in its development [76].

High spore concentrations were observed in both the dry and the rainy seasons. Cladosporium, Aspergillus/Penicillium, 
Curvularia, Nigrospora and Periconia registered peak concentration during the rainy and warmest months of the year (May-September). A similar trend was reported by others authors $[58,77]$. In addition, the main peaks of basidiospores (Coprinus and Ganoderma) were recorded during the rainy season (May-October), as Almaguer et al. [11] detected in this same area of study. In Puerto Rico, sensitization rates to Ganoderma applanatum and Pleurotus ostreatus spore extracts were reported in $30-12 \%$ of 33 allergy patients of this country [78]. In asthmatic children, the highest quartile of glucan (a component of the fungal cell wall used as a marker of fungal exposure) was associated with rising rates of emergency room visits [79]. In Cartagena, Colombia, sensitization amounts to Penicillium notatum was $28.3 \%$ in asthmatic patients [10]. In the same study, sensitization to house dust mites ranged between 54-74\%. Massarina and Chaetosphaerella, which were among the new genera detected, recorded peak spore concentrations during the rainy season in 2015, perhaps due to the impact of rain and temperatures on reproductive development. Some authors highlight the importance of ascospore release following rainfall events [80]. The remaining spore peaks occurred during the dry season (November-April).

This study examined correlations between weather-related variables and airborne spore concentrations for 13 spore types during the period 2011-2015, and reported on the detection of hitherto-unreported fungal spores during 2015. The findings indicated a positive correlation between airborne spore levels (mainly ascospores) and both relative humidity and rainfall. The correlation was strongest for Leptosphaeria and the newly-recorded Diaporthe.

Some aeromycological studies suggested that the abundance of airborne fungal spores in agricultural and urban settings increases with higher air temperature, relative humidity or precipitation levels. Rosas et al. [81] noted that in Mexico some ascospores predominated in the atmosphere during rainy periods. In this season, rainfall accelerates the development of fruiting bodies and the release of spores. These effects have also been reported in Puerto Rico and Cuba $[8,11]$. In the neotropical region of Cuba the rainfall season is also characterized by high temperatures as a consequence of increase in air humidity and water availability. In Nigeria, the highest fungal spore levels are observed during the rainy season (June-October) and at the start of the dry season (November-December). In this case, the relative humidity and temperature seem to be the most important weather conditions affecting the frequency of the spore types in the atmosphere [82].

Temperature was positively correlated with Curvularia, Nigrospora, Cercospora, Acrodictys and Arthrinium. A number of authors described that high temperatures favors conidia liberation in the atmosphere [70]. The abovementioned airborne fungi are mainly mesophilic with optimal growth temperature levels of $20-40^{\circ} \mathrm{C}$ [50]. In Western Cuba, the mean temperature is $25.5^{\circ} \mathrm{C}$; it is therefore likely that temperature exerts some influence during growth, sporulation and spore release.

The effects of weather-related factors may vary from year to year. In terms of the criteria set out by Ezike et al. [49], further monitoring is essential in order to accurately determine the correlation between airborne concentrations of these new fungal spores and weather-related variables. Changing weather patterns influence all natural ecological systems; here, weather variables could create conditions that facilitate the detection of airborne fungi spores.

\section{CONCLUSIONS}

In the course of this study carried out in Havana, Cuba, during 2015, 14 new fungal spores were identified and quantified using a non-viable volumetric sampling method. Many of them can cause respiratory disease and/or crop damage. It is therefore essential to determine and understand their reproductive cycle. A morphological description is provided of the newly-detected genera. Analysis of the influence of major weather-related variables on airborne spore concentrations showed that relative humidity was the most significant variable. The results obtained in this study may help in the design strategies aimed at preventing allergic respiratory disease and urban crop losses.

\section{Acknowledgments}

This study was part of the activities of the Competitive Reference Group (2015/008, Xunta de Galicia), the I. G. 1809-BIOAPLIC, University of Santiago, Spain and the Cuban National Project: PNH: P211LH007-017.

\section{REFERENCES}

1. Frenguelli G. The contribution of aerobiology to agriculture. Aerobiologia. 1998; 14(2-3): 95-100.

2. Mandrioli P, Ariatti A. Aerobiology: future course of action. Aerobiologia. 2001; 7(1): 1-10.

3. Haddrell AE, Thomas RJ. Aerobiology: experimental considerations, observations, and future tools. Appl Environ Microbiol. 2017; 83(17): e00809-17.

4. Ayesha T, Bhajbhuje MN. Diversity of air-borne mycoflora from indoor environment of library. Int J Life Sci. 2017; 5(2): 203-10.

5. Bezerra GFDB, Gomes SM, Silva MACND, Santos RMD, Muniz Filho WE, et al. Diversity and dynamics of airborne fungi in São Luis, State of Maranhão, Brazil. Rev Soc Bras MedTrop. 2014; 47(1):69-73.

6. Quintero E, Rivera-Mariani F, Bolaños-Rosero B. Analysis of environmental factors and their effects on fungal spores in the atmosphere of a tropical urban area (San Juan, Puerto Rico). Aerobiologia. 2010;26(2): 113-124.

7. Hasnain SMFK, Al-Frayg A, Al-Sedairy ST. Prevalence of airborne basidiospores in three coastal cities of Saudi Arabia. Aerobiologia. 2005; 21: 139-45.

8. Venero SJ, Varona P, Fabret D, Suárez R, Bonet M, Molina E. Asma bronquial y rinitis en escolares de Ciudad de La Habana (2001 a 2002). Revista Cubana de Higiene y Epidemiología. 2010; 47(1): 1-5.

9. Caraballo L, Zakzuk J, Lee BW, et al. Particularities of allergy in the Tropics. World Allergy Organ J. 2016; 9: 20. doi:10.1186/s40413-0160110-7.

10. Caraballo L, Puerta L, Fernandez-Caldas E, Lockey RF, Martinez B. Sensitization to mite allergens and acute asthma in a tropical environment. J Investig Allergol Clin Immunol. 1998; 8(5): 281-4

11. Almaguer M, Aira MJ, Rodríguez-Rajo FJ, Rojas TI. Study of airborne fungus spores by viable and non-viable methods in Havana, Cuba. Grana. 2013; 52(4): 289-298.

12. Sánchez KC, Almaguer M. Efecto de la temperatura sobre aislados de Cladosporium cladosporioides recolectados del aire de La Habana, Cuba. NACC. 2018; 25:21-29.

13. Fernández-González M, Ramos-Valcárcel D, Aira MJ, Rodríguez-Rajo FJ. Prediction of biological sensors appearance with ARIMA models as a tool for Integrated Pest Management protocols. Ann Agric Environ Med. 2016; 3(1): 129-37. doi: 10.5604/12321966.1196868.

14. Manzano JMM, Molina RT, Rodríguez SF, Barroso PD, Palacios IS, Garijo AG. Airborne propagules of Phytophthora and related taxa in SW Spain including a predictive model. Eur J Plant Pathol. 2015; 143(3): 473-483. 
15. Levetin E. Aerobiology of Agricultural Pathogens, p 3.2.8-1-3.2.8-20. In Yates M, Nakatsu C, Miller R, Pillai S (ed), Manual of Environmental Microbiology, Fourth Edition. ASM Press, Washington, DC. 2016.

16. Almaguer M, Rojas TI, Rodríguez-Rajo FJ, Aira MJ. Airborne fungal succession in a rice field of Cuba. Eur J Plant Pathol. 2012; 133: 473-482.

17. Di Carlo E, Chisesi R, Barresi G, Barbaro S, Lombardo G, Rotolo V, Sebastianelli M, Travagliato M, Palla F. Fungi and bacteria in indoor cultural heritage environments: microbial-related risks for artworks and human health. Environ Ecol Res. 2016; 4(5): 257-264.

18. Rojas TI, Aira MJ. Fungal biodiversity in indoor environments in Havana, Cuba. Aerobiologia. 2012; 28(3): 367-374.

19. Anaya M, Borrego S, Gámez E, Castro M, Molina A, Valdés O. Viable fungi in the air of indoor environments of the National Archive of the Republic of Cuba. Aerobiologia. 2016; 32: 513-527.

20. Prasla I, Duman K, Ciochetto Z, Burman A, Mahon A, Park S. et al. Significant heterogeneity in airborne mold quantities on the Caribbean Island of St. Kitts: Health implications and impact on food preservation. Virol Mycol. 2013; 3(1):1-5.

21. Ravikala KL, Nagalakshamma KV. Survey on outdoor airborne fungal spores of Tumkur city, Karnataka state, India. Int J Pharma BioSciences. 2016; 7(1): 575-577.

22. Almaguer M, Aira MJ, Rodríguez-Rajo FJ, Rojas TI. Temporal dynamics of airborne fungi in Havana (Cuba) during dry and rainy seasons: influence of meteorological parameters. Int J Biometeorol. 2014; 58(7): 1459-1470.

23. Katelaris $\mathrm{CH}$, Beggs, PJ. Climate change: allergens and allergic diseases. Internal Medicine Journal. 2018; 48(2): 129-134.

24. Castillo L, Pastrana JC. Diagnóstico del arbolado viario de El Vedado: composición, distribución y conflictos con el espacio construido. Arquitectura y Urbanismo. 2015; 36(2): 93-118.

25. Rosete CS, Pérez CJ, Ricardo NE, Sánchez O. Bosques de Cuba. Editorial Científico Técnica, La Habana, 2011.

26. Hirst JM. An automatic volumetric spore trap. Ann Appl Biol. 1952; 39: 257-65. doi:10.1111/j.1744-7348.1952.tb00904.x.

27. Galán, C., P. Cariñanos, P. Alcázar, and E. Dominguez. Manual of quality and management of the Spanish aerobiology network. Servicio de Publicaciones de la Universidad de Córdoba, Spain, 2007.

28. Cotos-Yáñez TR, Rodríguez-Rajo FJ, Pérez-González A, Aira MJ, Jato $\mathrm{V}$. Quality control in aerobiology: comparison different slide reading methods. Aerobiologia. 2013; 29(1): 1-11.

29. Oteros J, Galán C, Alcázar P, Domínguez-Vilches E. Quality control in bio-monitoring networks, Spanish Aerobiology Network. Sci. Total Environ. 2013; 443: 559-565.

30. Saccardo PA. Sylloge Fungorum. 1886; 4: 1-8.

31. Ellis MB. Dematiaceous Hyphomycetes. Commonwealth Mycological Institute, Kew, Survey, England, CMI, 1971

32. Ellis MB. More Dematiaceous Hyphomycetes. Commonwealth Mycological Institute, Kew. England, 1976.

33. Grant E. Sampling and identifying allergenic pollens and molds. Blewstone Press, San Antonio, 1990.

34. Hanlin RT. Illustrated genera of Ascomycetes. APS Press, 1990.

35. Hoog GS, Guarro J, Gené J, Figueras MJ. Atlas of Clinical Fungi. $2^{\text {nd }}$ edition Centraalbureau voor Schimmelcultures/ Universitat Rovira i Virgili, 2000.

36. Barnett HL, Hunter BB. Illustrated genera of imperfect fungi. (4th ed.). St Paul, Minnesota: APS Press, 2003.

37. Lacey ME, West JS. The Air Spore. Springer, Dordrecht, 2006

38. Seifert K, Morgan-Jhones G, Gams W, Kendrick B. The Genera of Hyphomycetes. CBS-KNAW Fungal Biodiversity Centre, Utrecht. The Netherlands, 2011.

39. Kamal M. New species of Corynespora. Mycol Res. 1998; 102(3): 344346.

40. Zhao GZ, Cao AX, Zhang TY, Liu XZ. Acrodictys (Hyphomycetes) and related genera from China. Mycol Progress. 2011; 10:67-83.

41. Zhang Y, Crous PW, Schoch CL, Hyde KD. Pleosporales. Fungal Diversity. 2012; 53(1): 1-221.

42. Crous PW, Groenewald JZ. A phylogenetic re-evaluation of Arthrinium. International Mycological Association. IMA fungus. 2013; 4(1): 133-154.

43. Stat. Soft Inc. STATISTICA for Windows. 2001; Computer program manual. Tulsa, OK.

44. Agashe SN, Caulton E. Pollen and Spores: Applications with special emphasis on Aerobiology and Allergy, CRC Press, 2009.

45. Kaczmarek J, Jędryczka M. Characterization of two coexisting pathogen populations of Leptosphaeria spp., the cause of stem canker of Brassicas. Acta Agrobotanica. 2001; 64(2):3-14.

46. Sabariego S, Díez A, Gutiérrez M. Monitoring of airborne fungi in Madrid (Spain). Acta Botanica Croata. 2007; 66(2): 117-126
47. Nikkels AH, Terstege P, Spieksma FThM. Ten types of microscopically identifiable airborne fungal spores at Leiden, The Nethertlands. Aerobiologia. 1996; 12: 107-112.

48. Hasnain S, Akhter T, Waqar M. Airborne and allergenic fungal spores of the Karachi environment and their correlation with meteorological factors. J Env Monit. 2012; 14: 1006-1013.

49. Ezike DN, Nnamani CV, Ogundipe OT, Adekanmbi OH. Airborne pollen and fungal spores in Garki, Abuja (North-Central Nigeria). Aerobiologia. 2016; 32:697-707.

50. Grinn-Gofron A. The variation in spore concentrations of selected fungal taxa associated with weather conditions in Szczecin, Poland, 2004-2006. Grana. 2008; 47(2): 139-146.

51. Ibáñez V, Villegas GR, Nolla JMR. Airborne fungi monitoring in Santiago, Chile. Aerobiologia. 2001; 17(2): 137-142.

52. Herrera L, Carrazana D, Quiñones, R. Los hongos anemófilos de la ciudad de Santa Clara, Cuba. Centro Agrícola. 2003; 3(30): 78-83.

53. Almaguer M, Sánchez KC, Díaz L. Lasiodiplodia theobromae en la atmósfera de La Habana. Revista Cubana de Ciencias Biológicas. 2016; 5(1): 130-134

54. Camino M, Mena J, Minter DW. Fungi of Cuba. www.cybertruffle.org. uk/cubafung (access: 2016.11.02).

55. Martyn E B. A note on banana leaf speckle in Jamaica and some associated fungi. Mycol Papers. 1945; 13: 1-5.

56. Huanyu L, Zhang R, Guangyu S, Batzer JC, Gleason ML. New species and record of Zygophiala on apple fruit from China. Mycol Progress. 2010; 9(2): 245-251.

57. Poonyth AD, Hyde KD, Aptroot A, Peerally A. Mauritiana rhizophorae gen. et sp. nov. (Ascomycetes, Requienellaceae), with a list of terrestrial saprobic mangrove fungi. Fungal Diversity. 2000; 4: 101-116.

58. Sousa L, Camacho IC, Grinn-Gofroń A, Camacho R. Monitoring of anamorphic fungal spores in Madeira region (Portugal), 2003-2008. Aerobiologia. 2016; 32(2), 303-315.

59. Green B, Sercombe J, Tovey E. Fungal fragments and undocumented conidia function as new aeroallergen sources. J Allergy Clin Immunol. 2005; 115: 1043-1048.

60. Mitakakis T, Guest D. A fungal spore calendar for the atmosphere of Melbourne, Australia, for the year 1993. Aerobiologia. 2001; 17: 171-176.

61. Herrero A D, Ruiz SS, Bustillo MG, Morales PC. Study of airborne fungal spores in Madrid, Spain. Aerobiologia. 2006; 22(2), 133.

62. Gonianakis M, Neonakis I, Darivianaki E, Gonianakis I, Bouros D. et al. Airborne Ascomycotina on the island of Crete: Seasonal patterns based on an 8-year volumetric survey. Aerobiologia. 2005; 21: 69-74.

63. Chew F, Lim S, Shang S, Dahlia S, Goh D et al. Evaluation of the allergenicity of tropical pollen and airborne spores in Singapore. Allergy. 2000; 55: 340-347.

64. Adhikari A, Sen M, Gupta-Bhattacharya S, Chanda S. Airborne viable, non-viable, and allergenic fungi in a rural agricultural area of India: a 2-year study at five outdoor sampling stations. Sci Total Env. 2004; 326: $23-141$

65. Das S, Gupta-Bhattacharya S. Monitoring and assessment of airborne fungi in Kolkata, India, by viable and non-viable air sampling methods. Env Monit Assess. 2012; 184: 4671-4684.

66. Simon-Nobbe B, Denk U, Pöll V, Rid R, Breitenbach M. The spectrum of fungal allergy. Int Archives Allergy Immunol. 2008; 145: 58-86.

67. Díez A, Sabariego S, Gutiérrez M, Cervigón C, Morales M. Study of airborne fungal spores in Madrid, Spain. Aerobiologia, 2006; 22: 135-142.

68. Martínez X, Tejera L, Beri Á. First volumetric record of fungal spores in the atmosphere of Montevideo City, Uruguay: a 2-year survey. Aerobiologia. 2016; 32: 317-333.

69. Almaguer M, Aira MJ, Rodríguez-Rajo FJ, Rojas TI. Thirty four identifiable airborne fungal spores at Havana, Cuba. Ann Agric Env Med. 2015; 22(2): 220-225.

70. Gaikwad K, Sonawane M. Fungi as bio-indicators of air quality. Int J Life Sci Pharm Reviews. 2012; 2(3), 25-28.

71. La-Serna I, Dopazo A, Aira MJ. Airborne fungal spores in the Campus of Anchieta (La Laguna, Tenerife). Grana. 2002; 41: 119-123.

72. Bruno A, Pace L, Tomassetti B, Coppola E, Verdecchia M et al. Estimation of fungal spore concentrations associated to meteorological variables. Aerobiologia. 2007; 23: 221-228.

73. Pyrri I, Kapsanaki-Gosti E. A comparative study on the airborne fungi in Athens, Greece, by viable and nonviable sampling methods. Aerobiologia. 2007; 23: 3-15.

74. Arnold GR. Lista de hongos fitopatógenos de Cuba. Ministerio de Cultura. Editorial científico técnico, Cuba, 1986.

75. Picos-Muñoz PA, García-Estrada RS, León-Félix J, Sañudo-Barajas A, Allende-Molar R. Lasiodiplodia theobromae en cultivos agrícolas 
de México: Taxonomía, Hospedantes, Diversidad y Control. Rev Mex Fitopatol. 2015; 33(1): 54-74.

76. Herrera A. Impacto de la agricultura urbana en Cuba. Novedades Población, CEDEM, Centro de Estudios Demográficos, Universidad de La Habana, 5(9): 1-14, 2009.

77. Ataygul E, Celenk S, Canitez Y, Bicakci A, Malyer H, Sapan N. Allergenic fungal spore concentrations in the atmosphere of Bursa, Turkey. J Biol Environ Sci. 2007; 1(2): 73-79.

78. Rivera-Mariani FE, Nazario-Jimenez S, Lopez-Malpica F, BolanosRosero B. Skin test reactivity of allergic subjects to basidiomycetes' crude extracts in a tropical environment. Med Mycol. 2011; 49(8): $887-91$.

79. Blatter J, Forno E, Brehm J, Acosta-Perez E, Alvarez M, Colon-Semidey A, Thorne PS, Metwali N, Canino G, Celedon JC. Fungal exposure, atopy, and asthma exacerbations in Puerto Rican children. Ann Am Thorac Soc. 2014; 11(6):925-32.

80. Crandall SG, Gilbert GS. Meteorological factors associated with abundance of airborne fungal spores over natural vegetation. Atmos Environ. 2017; 162: 87-99

81. Rosas I, McCartney HA, Payne RW, Calderon C, Lacey J, Chapela R, Ruiz-Velazco S. Analysis of the relationships between environmental factors (aeroallergens, air pollution, and weather) and asthma emergency admissions to a hospital in Mexico City. Allergy. 1998; 53(4): 394-401.

82. Njokuocha RC, Agwu CO, Okezie CE. Effects of weather conditions on selected airborne fungal spores in the Southern part of the Atate of Enugu, Nigeria. Grana. 2017; 56(4): 263-272. 